\title{
Impact of Oil Prices on GCC Stock Market
}

\author{
K. Ravichandran, Assistant Professor \\ College of Business Administration in Alkharj \\ King Saud University \\ P O Box 165, 11942, Alkharj, Saudi Arabia \\ E-mail: varshal2@yahoo.com \\ Khalid Abdullah Alkhathlan, Dean \\ College of Business Administration in Alkharj \\ King Saud University \\ P O Box 165, 11942, Alkharj, Saudi Arabia \\ E-mail:kaa8161@hotmail.com
}

\begin{abstract}
This paper investigates the impact of oil Prices on Gulf Cooperation Council (GCC) stock markets'. Since GCC countries are major suppliers of oil, their stock markets are likely to be susceptible to change in oil prices. The results confirm that there is an influence of oil price change on GCC stock markets returns in the long-term. Long term is defined here as the period of time required for the effect of oil price changes to work out its way to influence major macroeconomic indicators that influence profitability of firms traded in GCC stock markets.
\end{abstract}

Keywords: Stock Market Returns, GCC, NYMEX, Oil Price 


\section{Introduction:}

The six members of the Gulf Cooperation Council (GCC), Bahrain, Kuwait, Oman, Qatar, Saudi Arabia and United Arab

Emirates represent very promising emerging markets. With the exception of Bahrain, they are relatively unknown to most foreign investors. The GCC markets differ from those of developed countries and from other emerging markets in that they are largely segmented from the world equity markets and are overly sensitive to regional political events. While

Bahrain, Kuwait, and most recently, Qatar permit foreign stock ownership; Saudi Arabia allows foreign ownership only through investment in mutual funds. In GCC markets, fads or speculative attacks (which are rare) do not result from the rapid flow of capital into and out of markets as in other emerging markets. Instead, they often occur when domestic markets overheat. Restrictions on foreign ownership limit flows of 'hot money' into and out of GCC countries. The turnover, with the exception of Saudi Arabia and Kuwait, is relatively low for most markets. The number of publicly traded companies per market is relatively small, and they are owned by a very small percentage of the indigenous population. On the other hand, volatility can also be traced back to the types of these publicly traded companies that dominate the stock markets: largely banks, and real estate, construction, and communications companies. Herding, fads and speculative attacks occur in these companies because their returns are particularly uncertain. Combined with lax information disclosure requirements, this may cause problems of rash trading based on patchy news. The GCC economies are also oil-dependent, and on a daily or a weekly basis their oil prices take their cues from the futures prices for West Texas Intermediate (WTI), a primary crude oil stream traded on the New York Mercantile Exchange (NYMEX). GCC stock markets may also be sensitive to the daily or weekly movements of stock prices in the US stock exchanges because GCC investors invest in both sets of markets. Moreover, their exchange rates are effectively tied to the US dollar and their monetary policies and thus their short-term interest rates follow the US monetary policy and its short-term interest rates (Karam, 2001). Understanding the linkage of oil price volatility with Gulf Cooperation Council (GCC) stock markets returns is important for investors to make necessary investment decisions and for policy makers to adopt appropriate policies in managing stock markets. Research on volatility of stock markets returns have been approached in the literature from two different perspectives. In one approach, volatility of stock markets returns has been related to key macroeconomic indicators.

Several studies examined the effects of global, country and industry factors on the movements and volatilities of stock returns but not for the markets under consideration in this paper. Moreover, Grinold et al. (1989), Drummen and Zimmermann (1992), and Heston and Rouwenhorst (1994) all find that national factors dominate stock return volatilities although industry factors play a significant role. Jones and Kaul (1996) study the impact of global oil shocks on the equity prices in Canada, Japan, UK and the US. They find that only in the case of US and Canada can the impact of the oil shocks on real cash completely account for this reaction. Huang et al. (1996) examine the relationship between daily returns of oil futures and US stock returns, using an unrestricted VAR model. They find that oil futures returns lead 
some individual oil company stock returns but have negligible impact on the broad-based market indices such as the S\&P 500. In a more recent study, Sadorsky (1999) examines the links between the fuel oil prices and stock prices based on US monthly data from January 1947 to April 1996. Using an unrestricted VAR model that also includes short-term interest rate and industrial production he highlights the importance of oil price in explaining the movements of the other variables. Schwert (1989) employed vector auto regressive model (VAR) using bond returns, growth rate of producer price index, and the monetary base, as relevant macroeconomic indicators explaining volatility of stock market returns. King, Sentana, and Wadhwani (1994) employ a multivariate model using data for a number of developed and emerging markets to study the linkage between stock returns and observable factors, such as interest rates, industrial production, oil prices; and unobservable factors that are not reflected in the published data of stock markets. Their findings indicate that the unobservable factors play more significant role in explaining the volatility of stock returns. The other approach of modeling volatility of stock markets returns is by focusing exclusively on oil price volatility as a predictive indicator for stock market returns. This approach is motivated by research finding verifying existence of significant causal links between oil price change and key macroeconomic indicators. Hamilton (1983) argues that almost all United States recessions since the World War II have been preceded by oil shocks. In a survey article, Mork (1994) shows a negative correlation between oil prices and aggregate measures of output and employment for a group of oil importing countries. Wassal (2005) uses Johansen co-integration technique to show existence of long-run relationship between stock market indicators such as liquidity and size, with macroeconomic indicators for a number of oil exporting countries in Asia, Africa, and Latin America. Bashar (2005) employs VAR analysis to study the effect of oil price change on GCC stock markets, and shows that only Saudi and Muscat markets have predictive power of oil price increase. Hammoudeh and Aleisa (2004) use Johansen co-integration to examine the relation between oil prices and stock markets in GCC countries, and conclude that the Saudi market is the only market in the group that can be predicted by oil future prices.

King et al. (1994) employ a multivariate model using data for a number of developed and emerging markets to study the linkage between stock returns and observable factors, such as interest rates, industrial production, oil prices; and unobservable factors that are not reflected in the published data of stock markets. Their findings indicate that the unobservable factors play more significant role in explaining the volatility of stock returns. The other approach of modeling volatility of stock markets returns is by focusing exclusively on oil price volatility as a predictive indicator for stock market returns. This approach is motivated by research finding verifying existence of significant causal links between oil price change and key macroeconomic indicators. Hamilton (1983) argues that almost all US recessions since the Second World War have been preceded by oil shocks. In a survey paper, Mork (1994) shows a negative correlation between oil prices and aggregate measures of output and employment for a group of oil importing countries. EL-Wassal (2005) uses Johansen co-integration technique to show existence of long-run relationship between a number of stock market indicators such as liquidity and size, with macroeconomic indicators for a number of oil exporting countries in Asia, Africa, and Latin America.2 Bashar (2006) employs VAR 
analysis to study the effect of oil price change on GCC stock markets, and shows that only Saudi and Muscat markets have predictive power of oil price increase. Hammoudeh and Aleisa (2004) use Johansen co-integration to examine the relationship between oil prices and stock markets in GCC countries, and conclude that Saudi market is the only market in the group that can be predicted by oil future prices. One rational of using oil price change as a measure for change in key macroeconomic indicators is that value of stock prices in theory equals discounted expectation of future cash flows (dividends), which in turn are affected by macroeconomic events that possibly can be influenced by oil shocks. Despite the strong connection of oil revenues with almost all macroeconomic indicators in GCC economies, apparently the transmission mechanism of oil price shocks to stock market returns are ambiguous. Since oil price increase raises production cost in industrial oil consuming countries, oil price increase is expected to raise the cost of imported capital goods, therefore adversely affecting the prospects of higher profits for firms traded in GCC stock markets.

Since oil price change transmits its effect on GCC stock markets via its effect on relevant macroeconomic variables, it seems more appropriate to estimate the linkage between stock market prices and macroeconomic variables. However, this approach is not reliable in case of GCC countries because most GCC markets were established, as formally regulated markets only in the past six years. Thus, investigation of long-run relationship based on reliable time series models can be constrained by sample size problems. Unlike previous studies where the primary focus was an investigation of the link- age between oil price changes and stock markets prices, in this paper, the primary objective is to separate the effect of unobservable factors from oil price effect on GCC stock markets. To my understanding, this is an important and timely issue in GCC countries, as investors and policy makers in recent years have raised doubts about compatibility of GCC stock markets' behaviour with fundamentals of GCC economies.

\section{Data analysis}

Data employed in this study are daily stock market price indices and NYMEX oil price during the period 3 years March 2008 April 2010. After excluding the holiday periods the sample size constitutes 524 observations. As shown in table 1, the average returns of stock markets in GCC vary from 13 to 41 points where Qatar is being the highest and Bahrain being the lowest. The range of statistic indicates that all markets, except Bahrain and Kuwait markets, are skewed towards upward (positive) changes. Stock returns for Bahrain and Kuwait markets indicate almost equal chances of upward and downward changes. It is also to be noted that the standard deviation statistic shows that there is a considerable differences between variability in stock markets returns and oil price volatility. This may be regarded as informal indication of weak correlation between short-term variability of stock markets returns and oil price volatility. Phillips-Perron unit root tests indicate that levels of stock prices follow random walk behaviour, whereas it's first differenced series exhibit stationary behaviour. The Jarque-Bera test for joint normal kurtosis and skewness rejects the normality of residuals when autoregressive representation is considered for all price series. 
Table 1. Basic statistics

\begin{tabular}{|c|c|c|c|c|c|c|c|}
\hline & Oman & Kuwait & Saudi & Bahrain & Qatar & UAE & Oil price \\
\hline Mean & 27.98 & 25 & 41.24 & 13.03 & 44.82 & 41.08 & 57.32 \\
\hline St. deviation & 246.36 & 395 & 375.09 & 42.50 & 504.95 & 153.44 & 13.66 \\
\hline Minimum & -226.56 & -641.03 & -391.71 & -95.83 & -577.07 & -243.00 & 31.04 \\
\hline Maximum & 498.92 & 754.04 & 791.34 & 35.05 & 1234.61 & 211.96 & 74.30 \\
\hline $\begin{array}{c}\text { Unit root } \\
\text { test: }\end{array}$ & & & & & & & \\
\hline $\begin{array}{c}\text { level } \\
\text { 1st difference }\end{array}$ & $148.2 *$ & $127.06 * 171.04 * 162.82 .3 * 136.54 * 276.31 .4 *$ & $189.4 *$ \\
\hline $\begin{array}{c}\text { Jarque-Bera } \\
\text { (p-value) }\end{array}$ & $(0.04)$ & $(0.00)$ & $(0.04)$ & $(0.00)$ & $(0.00)$ & $(0.01)$ & $(0.00)$ \\
\hline
\end{tabular}

*Significant at 95 per cent significance level.

\section{Co-integration}

Co-integration of a number of variables implies some linear combination of two or more variables yield stationary series, even though each of the series is non-stationary and some long-run equilibrium relation ties the individual series together. When variables are not co-integrated, VAR equations in first differences are tested. Error representation theorem of Engel and Granger (1987), implies that co-integrated variables can be represented in error correction model (ECM), and regressing the first difference of co-integrated variables result in misspecification error. To avoid the problem of misspecification, they suggest an error correction model that includes lagged errors of co-integrated regression as an independent variable, beside the first differenced co-integrated variables in the regression equations. To investigate existence of long-term relationship between change in oil price and GCC stock market prices on one hand and between changes in oil price and turn-over ratios (liquidity indicator) on the other, we employed the multivariate approach of Johansen and Juselius (JJ) (1990), at the five per cent significance level.

Table 2 includes co-integration results and indicates that the number of co-integrating vectors increased from one co- integrating vector when only stock prices are considered, to three that co-integrating vectors when turn-over ratios instead are accounted for. This result suggests, change in oil prices has more effect on the liquidity of GCC stock as compared to stock prices. Intuitively, as indicated in table 2, liquidity of a market is proportional to the market size, and that implies that the bigger the economy (oil-based) the stronger its connection with oil prices. Thus, oil price transmits its effect on key macroeconomic indicators that in turn, influence liquidity indicators; whereas oil price effect on stock prices is distorted by speculative and 
markets inefficiency behaviour.

Table 2. Co-integration analysis

\begin{tabular}{|l|l|l|l|l|l|}
\hline \multicolumn{6}{|l|}{ 1. Co-integration of stock prices and oil prices } \\
\hline $\mathbf{H}$ & $\mathbf{H}$ & $\begin{array}{l}\mathbf{L}_{\mathbf{m a x}} \\
\text { statistics }\end{array}$ & $\begin{array}{l}\text { Critical } \\
\text { values }\end{array}$ & $\begin{array}{l}\mathbf{L}_{\text {trace }} \\
\text { statistics }\end{array}$ & $\begin{array}{l}\text { Critical } \\
\text { values }\end{array}$ \\
\hline $\mathrm{r}=0$ & $\mathrm{r}=1$ & 63.5 & 19.1 & $514.12^{*}$ & 35.8 \\
\hline $\mathrm{r} \delta$ 1 & $\mathrm{r}=2$ & 19.7 & 37.6 & 97.6 & 45.9 \\
\hline $\mathrm{r} \delta 2$ & $\mathrm{r}=3$ & 15.4 & 38.4 & 84.3 & 62.7 \\
\hline $\mathrm{r} \delta 3$ & $\mathrm{r}=4$ & 11.0 & 41.5 & 56.4 & 97.5 \\
\hline $\mathrm{r} \delta$ 4 & $\mathrm{r}=5$ & 9.1 & 48.3 & 11.5 & 136.5 \\
\hline 2. Co-integration of turn-over ratios and oil prices & \\
\hline $\mathrm{r}=0$ & $\mathrm{r}=1$ & $124.48^{*}$ & 21.05 & $358.7^{*}$ & 35.8 \\
\hline $\mathrm{r} \delta 1$ & $\mathrm{r}=2$ & $72.4^{*}$ & 29.51 & $254.6^{*}$ & 45.9 \\
\hline $\mathrm{r} \delta 2$ & $\mathrm{r}=3$ & $49.57^{*}$ & 32.6 & $111.5^{*}$ & 62.7 \\
\hline $\mathrm{r} \delta 3$ & $\mathrm{r}=4$ & 31.07 & 43.5 & 97.6 & 97.5 \\
\hline $\mathrm{r} \delta$ 4 & $\mathrm{r}=5$ & 29.71 & 51.1 & 57.8 & 136.5 \\
\hline
\end{tabular}

Significant at five per cent significance level.

\subsection{Estimation results}

Investigation of oil price volatility spillover on GCC stock markets requires determining the structure of volatility in oil price data. Given evidence of time-dependent volatility behaviour for oil price data (LM test, Table 2), we employ the following GARCH-M model to consider the impact of oil price uncertainty on GCC stock market returns. Unobservable factors represented by random walk error term; and volatility of oil price.

$$
\Delta P_{t}=\alpha_{i}+\sum_{i=1}^{p} \alpha_{i} \Delta P_{t-1}+m v_{t}+\epsilon_{i}
$$

$$
\text { where } \in \square N\left(0, v_{t}\right), v_{t}=\partial_{0}+\partial_{1}+\partial_{1} v_{t-1}+\partial \epsilon_{t-1}^{2}
$$

and

$$
\begin{array}{r}
\Delta s_{t}=\beta_{0}+\sum_{i-1}^{n} \beta_{1} \Delta s_{t-i}+\Phi \ell_{t}+\sum_{i=0}^{p_{1}} \theta_{1} v_{t-1}+\omega_{t} \\
\text { where } \omega \square \operatorname{st} t(\omega \backslash n)
\end{array}
$$

where $s_{t}$ and $p_{t}$, respectively, denote stock prices and oil price. The variable $e_{t}$ is random walk residuals computed from unit root test results evidenced in Table 2, and this variable is 
intended to capture unobservable factors, which are not reflected in the published data of stock markets. Bollerslev et al. (2003) indicate that ARCH models with conditional normal errors result in a leptokurtic unconditional distribution. However, the degree of leptokurtosis induced by the time-varying conditional variance often does not capture all of the leptokurtosis present in high-frequency speculative prices. To circumvent this problem, Bollerslev (1987) suggests the use of Student $t$-distribution with degrees of freedom greater than two. Thus, the error term in equation (2) is assumed to follow the density function:

$$
f(\omega \backslash n)=\frac{\Gamma(n=1) / 2}{\sqrt{n \pi \Gamma(n / 2)}}\left[\frac{n}{n+\omega^{2}}\right] \text { for }-\infty<\omega<\infty
$$

Where $\Gamma($.$) denotes gamma function.$

We employed maximum likelihood method to estimate parameters in equation (2).

The statistical significance of coefficients for all markets implies that in the short term, non-observable speculative factors are the driving force of GCC stock returns, whereas the insignificance of co-efficient for Saudi and Bahrain stock markets indicate while the effect of oil price volatility is insignificant, the effect of the unobservable speculative factors is the dominant driving force determining short-term stock price returns. However, for the other four markets, the speculative factors and oil price uncertainty work together, though in opposite directions to determine the short-term stock price returns.

Table 3. Estimation of Parameters

\begin{tabular}{|l|l|l|l|l|l|l|}
\hline & Bahrain & Kuwait & Oman & Saudi & UAE & Qatar \\
\hline$\beta_{0}$ & -11.4 & 42.10 & 73.45 & 56.24 & 23.78 & 36.12 \\
& $(0.04)$ & $(0.00)$ & $(0.03)$ & $(0.04)$ & $(0.04)$ & $(0.05)$ \\
\hline$\beta 1$ & -1.1 & -3.45 & 23.45 & -1.04 & -0.45 & -1.78 \\
& $(0.00)$ & $(0.00)$ & $(0.00)$ & $(0.00)$ & $(0.00)$ & $(0.01)$ \\
\hline$\Phi$ & 0.95 & 1.12 & 4.45 & 0.92 & 0.91 & 0.95 \\
& $(0.00)$ & $(0.00)$ & $(0.00)$ & $(0.00)$ & $(0.00)$ & $(0.00)$ \\
\hline$\theta_{1}$ & 1.45 & 12.56 & -11.42 & -19.12 & -1.68 & -2.12 \\
& $(0.51)$ & $(0.15)$ & $(0.05)$ & $(0.02)$ & $(0.05)$ & $(0.02)$ \\
\hline$\theta_{2}$ & 0.98 & 0.97 & -3.47 & -4.14 & 0.99 & 0.87 \\
& $(0.14)$ & $(0.00)$ & $(0.010)$ & $(0.01)$ & $(0.00)$ & $(0.00)$ \\
\hline$\theta_{3}$ & 0.05 & -4.12 & -0.02 & 6.78 & -5.17 & -0.12 \\
& $(0.00)$ & $(0.00)$ & $(0.00)$ & $(0.40)$ & $(0.01)$ & $(0.02)$ \\
\hline LLF & -2315 & -1945 & -2915 & -3412 & -2649 & -1745 \\
\hline
\end{tabular}

Terms in parenthesis are p-values

Estimation results for the parameters in the system of equations 3 summarised in table 3 . The statistical significance of coefficients for all markets, except Muscat, imply in the short-term that non-observable speculative factors are the driving force of GCC stock returns; whereas the insignificance of coefficients imply that oil price volatility is ineffective in determining the short term changes in stock market returns. It should be realized that for Muscat market, the coefficient is insignificant, because the e variable in equation 3 is not a random walk as 
indicated in table 1. Therefore, its effect is similar to the effect of other observable factors such as oil price volatility. Also indicated in the table, there is significant one day lag effect of stock returns in four of GCC markets. This implies news and information from previous day carried on to the following trading day. The serial correlation of daily stock returns is viewed as additional evidence supporting the dominance of short-run speculative factors in those markets.

\section{Concluding remarks}

The main purpose of this paper is to investigate the role of each of these two conditions in explaining short-term change in GCC stock markets. Kuwait and Bahrain stock markets are speculative markets, dominated by the influence of non-predictable speculative factors, but for the other four markets, the speculative effects and oil price uncertainty work together in opposite directions to determine stock prices. In the long-term, the influence of oil price on GCC stock prices prevail, as oil price effect transmits to macroeconomic indicators that influence liquidity of these markets. This suggests that the effect of oil price changes transmit to fundamental macroeconomic indicators, which in turn affect the long-term equilibrium linkage between these markets. Conditions that reflect change in observable factors that affect an economy. Second, there are speculative factors that operate entirely within a market over short periods. These two sets of conditions sometimes work together, and sometimes opposite. Thus, a given market can be speculatively strong, but fundamentally weak, or the reverse. The long term in our perspective is realized when oil price changes transmit to major macroeconomic indicators that influence the profitability of firms traded in GCC stock markets. Future researches can be undertaken to find out the influence of various economic factors over GCC stock markets keeping oil prices as constant. This kind of researches will throw light economies which are oil based and simultaneously help them to increase the performance of their stock markets.

\section{References}

Arshanapalli B., J., Doukas and L., Lang (.1995). Pre- and-post-October 1987 stock market linkages between US and Asian markets. Pacific Basin Finance Journal, No. 3, p. 57.

Bashar, Z. (2006). Wild oil prices, but brave stock markets! The case of Gulf Cooperation Council (GCC) stock markets. Middle East Economic Association Conference, Dubai, United Arab Emirates.

Beckers, S., Connor, G., and Curds, R. (1995). National versus global factors in equity returns. LSE Financial Markets Group, London, Unpublished working paper.

Bekaert, G., and C., Harvey (1995). Time varying world market integration. Journal of Finance, No. 50, pp. 403-44.

Bourland B. (2001). GCC: outward investment glows, inward investment needs. unpublished paper presented at the Middle East Conference, London, United Kingdom.

Crowder, W.J., and Wohar, M.E. (1998). Co-integration, forecasting and international stock prices. Global Finance. J, 181-204. 
Dar, H.A., and Presley, J.R. (2001). The Gulf Cooperation Council: a slow path to integration? World Econ, 24, 1161-1178.

DeJong, D., J., Nankervis, N., Savin and C., Whiteman. (1992a). Integration versus trend stationarity in macroeconomic time-series. Econometrica, Vol. 60, pp. 423-34.

Dicky, D.A., and W.A., Fuller (1979). Distribution of the estimators for autoregressive time-series with a unit toot. Journal of American Statistical Association, Vol. 74, pp. 427-31.

Dicky, D.A., and W.A., Fuller. (1981). Likelihood ratio statistics for autoregressive timeseries with a unit root. Econometrica, Vol. 49, pp. 1057-72.

Drummen, M., and Zimmermann, H. (1992). The structure of European stock returns. Finan. Analyst J. 48, 15-26.

Eun C., and S., Shim (1989). International transmission of stock market movement. Journal of Financial and Quantitative Analysis, Vol. 24, pp. 241-56.

Fasano, U., and Iqbal, I. (2003). GCCCountries: from oil dependence to diversification. I.M.F,Washington, Unpublished IMF working paper.

Goldstein, M. (1998). The Asian financial crisis: causes, cures and systemic implications. Institute for International Economic publication.

Gonzalo, J. (1994). Five alternative methods of estimating long run relationships. J. Economics. 60, 203-233.

Granger, C. (1980). Testing for causality - a personal view point. Journal of Economic Dynamic and Control, Vol. 2, pp. 329-52.

Greene, W. (1993). Econometric Analysis. 2nd Edition, MacMillan.

Grinold, R., Rudd, A., and Stefek, D. (1989). Global factors: fact or fiction? J. Portfolio Manage. 16, 79-88.

Hamao, Y., Ronald W., Masulis, and V., Ng (1989). Correlation in price changes and volatility across international stock markets. Review of Financial Studies, Vol. 3, pp. 281-307.

Hamilton, J. (1983). Oil and the macro economy since World War II. Journal of Political Economy, 91, pp. 228-48.

Hammoudeh, S. (1996). Oil price, mean reversion and readjustments. Southern Econ. J. 62 (2), 916-919.

Hammoudeh, S., and Alesia, E. (2004). Links and volatility transmission between NYMEX oil futures and the GCC stock market indices. Contemp. Econ. Policy, 22, 250-269.

Hammoudeh, S., and E., Aleisa (2004). Dynamic relationship among GCC stock markets and NYMEX oil futures. Contemporary Economic Policy, Vol. 22, pp. 250-69. 
Hammoudeh, S., and Choi, K. (2005). Characteristics of the permanent and transitory returns in the oil-sensitive emerging stock markets: the case of the GCC Countries. Drexel University, Philadelphia, Unpublished working paper.

Hammoudeh, S., Ewing, B., and Zhao, G. (2003). Oil and natural gas sensitivity, asymmetry, systematic risk and skewness in the Russian stock market. Working paper, Drexel University, Philadelphia, PA.

Hammoudeh, S., and Li, H. (2003). The impact of the Asian crisis on the behavior of US and international petroleum prices. Ener. Econ. 26, 135-160.

Hammoudeh, S., and Li, H. (2005). Oil sensitivity and systematic risk in oil-sensitive stock indices. J. Econ. Business, 57, 1-21.

Hansen, H., and Juselius, K. (1995). CATS in RATS; Co-integration Analysis of Time Series. Estima, Evanston, IL.

Hargreaves, C. (1994). A review of methods of estimating co-integration relationships. In: Hargreaves, C. (Ed.), Non-stationary Time Series Analysis and Co-integration. Oxford University Press, Oxford.

Hendry, D., and Juselius, K. (2001). Explaining co-integration analysis: part II. Ener. J. 22, 75-120.

Heston, S.L., and Rouwenhorst, K.G. (1994). Does industrial structure explain the benefits of international diversification? J. Finan. Econ. 36, 3-27.

Huang, R., Masulis, R., and Stoll, H. (1996). Energy shocks and financial markets. J. Futures Markets 16, 1-27.

Johansen, S., 1988. Statistical analysis of co-integration vectors. J. Econ. Dynamics Control, $12,231-254$.

Johansen, S., and K., Juseilus. (1990). Maximum likelihood estimation and inference on co-integration with application to the demand for money. Oxford Bulletin of Economics and Statistics, No. 52, pp. 169-210.

Johansen, S., and Juselius, K. (1990). Maximum likelihood estimation and inferences on co-integration-with applications to demand for money. Oxford Bull. Econ. Stat. 54, 383-397.

Jones, C., and Kaul, G. (1996). Oil and stock markets. J. Finance. 51, 463-491.

Karam, P. (2001). Exchange rate policies in Arab countries: assessment and recommendation. Economic Policy Institute, Arab Monetary Fund, UAE, Unpublished working paper.

King M., and S. Wadhwani. (1994). Volatility and links between national stock markets. Econometrica, Vol. 62/4, pp. 901-33.

King M., and S., Wadhwani. (1990). Transmission of volatility between stock markets. Review of Financial Studies, Vol. 3, pp. 5-33. 
Kwiatkowski, D., P., Phillips, P., Schmidt, and Y., Shin. (1992). Testing the null hypothesis of stationarity against the alternatives of a unit root: how sure are we that economic time- series save a unit root?. Journal of Econometrics, Vol. 54, pp. 159-78.

Kwiatkowski, D., Phillips, P.C., Schmidt, P., and Shin, Y. (1992). Testing the null hypothesis of stationarity against the alternative of a unit root. J. Econom. 54, 78-159.

Lee, S., and K., Kim. (1993). Does the October 1987 crash strengthen the co-movements among national stock markets?. Review of Financial Economics, Vol. 3, pp. 89-102.

Longin, F., and B., Solnik. (1995). Is correlation in international equity returns constant: 1960-90. Journal of International Money and Finance, Vol. 14, pp. 3-26.

Longin, F., and B., Solnik. (2001). Extreme correlation of international equity markets. Journal of Finance, Vol. 56, pp. 649-76.

Malik, F., Hammoudeh, S., 2004. Shock and volatility transmission in the NYMEX oil, US and Gulf equity markets. In: Paper presented at the Middle East Economic Association Meeting, San Diego, CA.

Masih A., and R., Masih (1997). Dynamic linkages and the propagation mechanism driving major international stock markets. Quarterly Review of Economics and Finance, Vol.37, pp. 859-85.

Mork, K. (1994). Business cycles and the oil market (special issue). Energy Journal, Vol. 15, pp. 15-37.

Ng, S. and P. Perron (1993b), "Unit root tests in ARMA models with data dependent methods for the selection of the truncation lag, (manuscript), C.R.D.E., University of Montreal, Quebec, Canada.

Perron, P., 1989. The great crash, the oil price shock and the unit root hypothesis. Econometrica, 57, 1361-1401.

Phillips, P. (1987). Time-series regression with a unit root. Econometrica, Vol 55, pp. 277-301.

Phillips, P. (1988). Trends and random walks in macroeconomic time-series. Journal of Economic Dynamics and Control, Vol. 12, pp. 297-332.

Phillips, P.C.B., and Perron, P. (1988). Testing for a unit root in time series regression. Biometra, 75, 335-346.

Rigobon, R. (2001). Contagion: how to measure it. working paper 8118.

NBER. Rigobon, R. (2002). On the international propagation of shocks: is it stable?. Journal of International Economics, forthcoming.

Roll, R. (1989). The international crash of October 1987. Financial Analysis Journal, Vol. 44, pp. 19-35. 
Sadorsky, P., 1999. Oil price shocks and stock market activity. Energy Econ, 21, 449-469.

Schwert, G. (1989).Why does stock market volatility change over time?. Journal of Finance, 44, pp. 5, 1115-53.

Tang, L., and Hammoudeh, S. (2002). An empirical exploration of the world oil price under the target zone model. Energy Econ, 24, 577-596.

Teweles R., E. Bradley, and T., Teweles. (1992). The stock market, 6th ed., Western Wiley.

Tuluca S., and B., Zwick. (2001). The effects of the Asian crisis on global equity markets. Financial Review, No. 36, pp. 125-42.

Wassal, K. (2005). Stock market growth: an analysis of co-integration and causality. Economic Issues, Vol. 10, pp 37-58.

Whistler, D., K., White, D., Wong, and Shazam D. Bates, Software and Users Reference Manual, Version 10, Northwest Econometrics Ltd.Assaf, A., 2003. Transmission of stock price movements: the case of GCC stock markets. Rev. Middle East Econ.Finan. 1, 89-171.

Zivot, E., and Andrews,W.K., 1992. Further evidence on the great crash, the oil-price shock, and the unit-root hypothesis. J. Business Econ. Studies, 10 (3), 25-44. 